
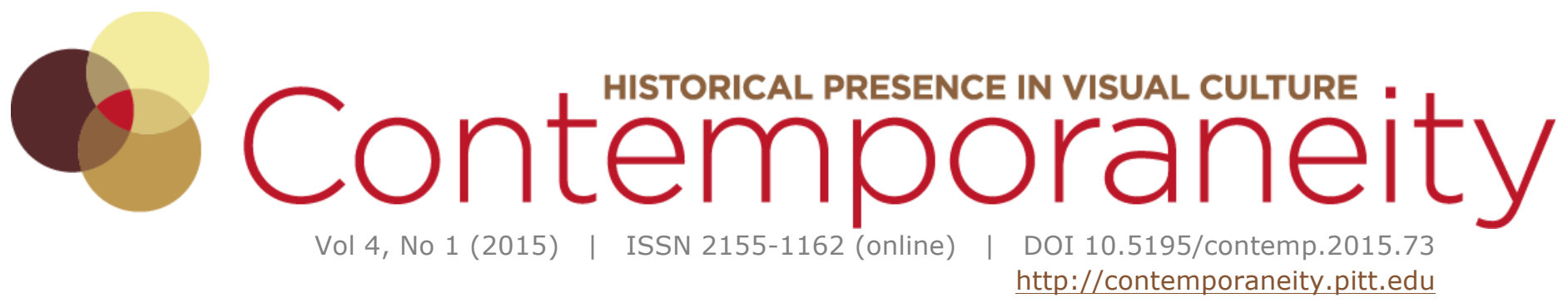

\title{
"Enlivening and - Dividing" An Aporia of Illumination
}

\author{
Hans Christian Hönes
}

\section{Abstract}

In 1798, Karl August Böttiger paid a nocturnal visit to the Gallery of Antiques in Dresden, illuminating the statues with a torch. At first glance, this seems to be yet another example of a popular practice for visiting galleries c.1800. Illuminating the sculptures by torchlight was a popular means of enlivening the objects, set in motion by the light flickering on their surfaces. The collections were thus meant to become a place where cold, white stone comes to life, and where the beholder becomes part of a revived antiquity.

This was precisely what Böttiger intended, too. But to him, the effect of the torchlight appeared to be, as he wrote, "enlivening and - dividing!" The torchlight highlighted not only the beauty of the sculptures but also their modern restorations. Böttiger apparently failed to experience the living presence of the antique celebrated by many of his contemporaries (e.g. Goethe, Moritz).

This essay focuses on the consequence of such a perception of sculptures as historically multi-layered objects. Böttiger's experience resulted in a problematic situation. In trying to view the sculptures as contemporaries, he hoped to become ancient himself. But this operation failed in the moment when the sculptures themselves appeared to be anachronistic, impure palimpsests. In consequence, galleries may not only be the place were art history as chronological Stilgeschichte was born. They may also be the site where this perception changed into the experience of a more chaotic shape of time.

\section{About the Author}

Hans Christian Hönes is a Research Associate on the project Bilderfahrzeuge: Warburg's Legacy and the Future of Iconology at the Warburg Institute in London. He is the author of Kunst am Ursprung: Das Nachleben der Bilder und die Souveränität des Antiquars (Bielefeld: transcript, 2014) and co-editor of volume IV of Aby Warburg's Gesammelte Schriften (Fragmente zur Ausdruckskunde auf anthropologischer Grundlage, Berlin: De Gruyter, 2015). 


\section{"Enlivening and - Dividing"}

\section{An Aporia of Illumination}

In 1798, the German archaeologist Karl August Böttiger paid a nocturnal visit to the gallery of antiques in Dresden, one of the most important collections of that time in Europe (Fig. 1). ${ }^{1} \mathrm{He}$ did not view the statues in bright daylight. Instead, they were illuminated by Böttiger's torch, as he acted as the cicerone of a group of "lovers of the arts, who attended and prepared for that event already some days in advance." This visit was not a unique event; other nocturnal visits with Böttiger as guide are reported, some with famous visitors including Hegel and Jean Paul. ${ }^{2}$ Böttiger published his impressions and experiences with this kind of artificial illumination in a short disquisition, printed privately in the same year and again ten years later in the journal Prometheus. ${ }^{3}$

Böttiger articulated his expectations for this visit in a straightforward manner. The effect of the illumination was "comparable to the touch of a Promethean torch." As an epigram for his text, he quoted a few lines by Herder, speaking of the "torch of life," whose blaze soaks the dead stone. In the flickering light of the torch, the visitor expected a more or less mystical experience, whereby the dead, white stone should be bathed in warm light and lively animation. ${ }^{4}$ The statue should become "a human form, animated by sunfire. ${ }^{5}$ This formulation comes quite unexpectedly, because, of all means of lighting, Böttiger did not chose the sun to illuminate the figures. The message is, nevertheless, clear. Böttiger desired to emulate what Prometheus had once achieved: to bring the statues to life.

\footnotetext{
${ }^{1}$ On the history of the Dresden collection, see: Hildegard Gabriele Boller, "Die Dresdner Antikensammlung," in Tempel der Kunst: Die Geburt des öffentlichen Museums in Deutschland, 1701-1815, ed. Bénédicte Savoy (Mainz: Zabern, 2006), 117144.

2 "In Böttigers Vorlesung war ich gestern; heute Abend will er uns die Antiken im Fackelschein zeigen." Georg W.F. Hegel, Briefe von und an Hegel, 1813-1822, vol. 2, ed. Johannes Hoffmeister (Hamburg: Meiner, 1969), 293; Jean Paul, "Titan," in Werke. Titan / Komischer Anhang zum Titan / Clavis Fichtiana seu Leibgeberiana, $6^{\text {th }}$ ed., ed. Norbert Miller (München/Wien: Hanser, 1999), 178; see also the commentary ibid., 1079.

${ }^{3}$ Karl August Böttiger, Die Dresdner Antikengalerie mit Fackel-beleuchtung gesehen den 25 August 1798 (Dresden: private print, 1798). Republished under the same title in Prometheus 2 (1808): 3-9. This account is, as René Sternke wrote, "part of a larger, handwritten account of his stay in Dresden." René Sternke, Böttiger und der archäologische Diskurs (Berlin: Akademie, 2008), 228. Cf. Sächsische Landes- und Universitätsbibliothek Msc. Dresd. H 37 verm. $4^{\circ}$, viii, Nr. 16. All translations are the author's unless otherwise stated.

4 "Man kann eine solche Beleuchtung mit der Berührung einer Prometheus-fackel vergleichen"; the quote by Herder says: "O welchen Schatz des Holden und des Guten / Hast du, o Kunst, in manchen Stein gesenkt! / Wie quillt's hervor, wenn mit den Flammengluten, / Den todten Stein die Lebensfackel tränkt!" Böttiger, Dresdner Antikengalerie, 1. Strangely, this enthusiastic reception of an artwork seems to be quite the contrary to the sober and still beholding Herder propagated in his other writings. Cf. Erik Forssman, Goethezeit (München/Berlin: Deutscher Kunstverlag, 1999), 147.
}

${ }^{5}$ Karl August Böttiger, Ideen zur Kunst-Mythologie. Erster Cursus (Dresden/Leipzig: Arnold, 1826), 3. 


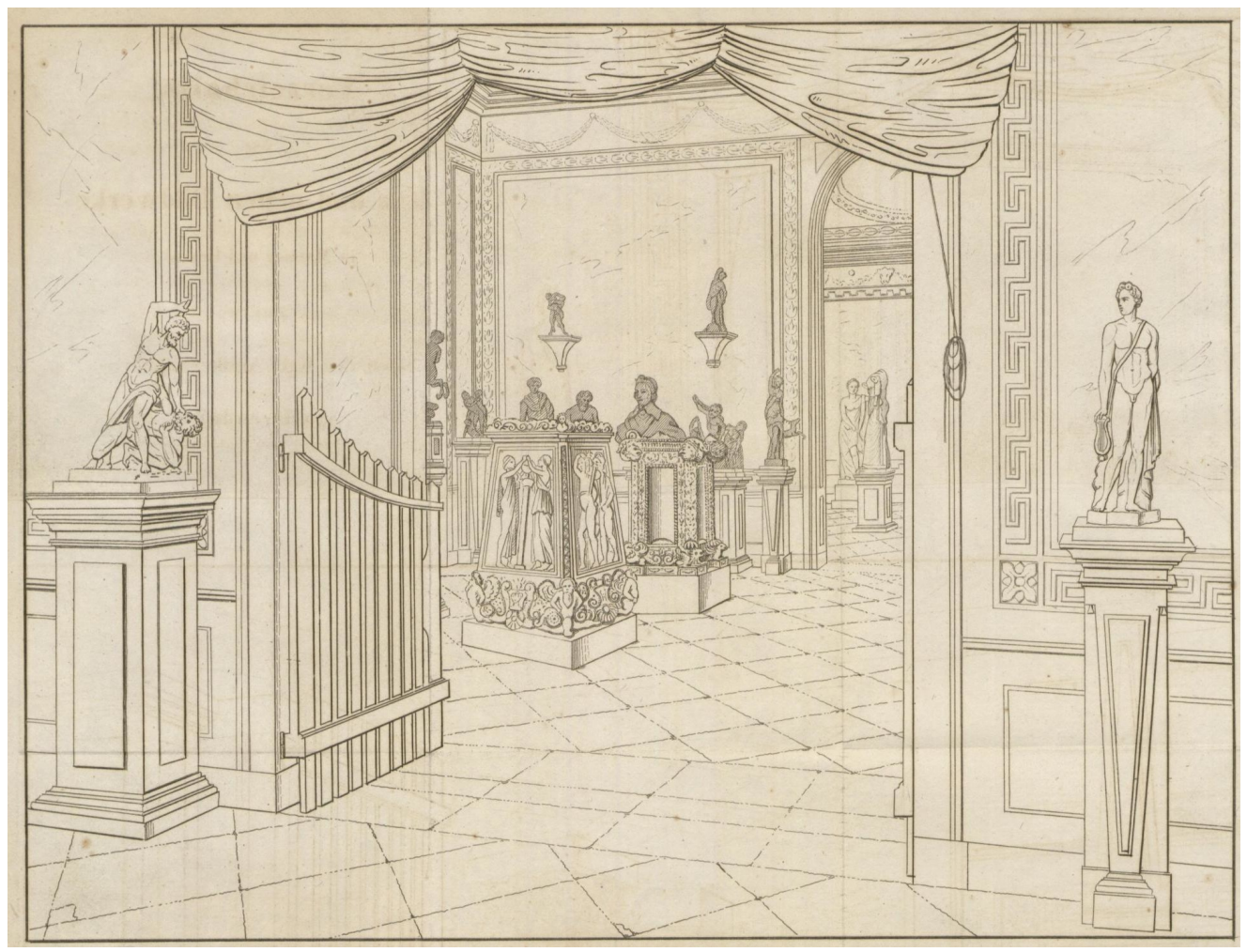

\section{Figure 1}

Interior of the Dresden Gallery of Antiques, from Heinrich Hase, Verzeichniß der alten und neuen Bildwerke in Marmor und Bronze in den Sälen der Kgl. Antikensammlung zu Dresden (Dresden: Walther, 1826), frontispiece (photo: author).

At first sight, Böttiger found what he was looking for: "everything real is springing up animatedly." However, his grand expectations were soon to be disappointed. The effect of the illumination was not untroubled pleasure, but rather proved to be - as he wrote "enlivening and - dividing" (belebend und - trennend). The torchlight also illuminated what Böttiger did not want to see, that which he considered not to be "real": "Even the untrained eye will recognize the sins of the restorers, the ignorance of Cavaceppi, or of even worse fellows. ${ }^{\prime 6}$ The beauty of the antique, which Böttiger hoped to enliven by torchlight, was

\footnotetext{
${ }^{6}$ Böttiger, Dresdner Antikengalerie, 1. It's an amusing footnote to our subject matter that, contrary to Böttiger, Bartolommeo Cavaceppi granted the Dresden collection, maybe not surprisingly, the highest praise. K.W. Dassdorf, estimating Cavaceppi to be "one of the greatest artist still alive," reported that he claimed that in Dresden he found "eine bewundernswürdige Menge von Statuen, Büsten, erhabenen Arbeiten, kurz mit Stücken vom höchsten Werthe," and he was "Erstaunt über eine so reiche und schöne Sammlung." Karl Wilhelm Dassdorf, Beschreibung der vorzüglichsten Merkwürdigkeiten der Churfürstlichen Residenzstadt Dresden und einiger seiner umliegenden Gegenden (Dresden: Walther, 1782), 552.
} 
apparently contaminated by later restorations. "All later patches appear ugly and crude"; ${ }^{7}$ indeed, they kept Böttiger from experiencing the figures' living presence.

The effect of the torchlight was contrary to what was intended. The statues appeared "transfigured" only at the moment when the light of the torch hides more than it illuminates. So it was in the case of an Aesculap (Fig. 2), which did seem to begin to move when lit by the flame, but was beautiful and enjoyable only "because the spiritual torch illuminated only the beautiful upper parts of the figure, and cloaked the horror the restoration did to the drapery and discarnate extremities." ${ }^{\prime 8}$

Such disappointed, or at least ambivalent, reactions to the fashionable practice of illuminating antique sculpture by torchlight, have been, as far as I can see, overlooked by art history. ${ }^{9}$ Yet Böttiger was by no means the only one to criticize the practice of illuminating statues with torches. Several years later, for example, an Englishman claimed that lighting from above was much more suitable for viewing the artworks than the permanent flicker of the torches was. $^{10}$

Still, Böttiger's reaction was quite different from such practical objections. His short disquisition is even more interesting because he claimed to have felt and seen the total opposite of what nearly all of his contemporaries described in writing about their experiences with these popular nocturnal visits. At that time nocturnal gallery visits still seemed new and exciting. Earlier cases could be named, starting at the latest with Benvenuto Cellini, but the true craze for visiting galleries at night began only in the $1780 \mathrm{s.}^{11}$

\footnotetext{
7 "Wie hässlich und plump erscheint alles angeflickte Machwerk." Böttiger, Dresdner Antikengalerie, 1.

8 "Auf seinen Heil-bedeutenden Schlangenstab gestützt schien uns der Gott wirklich im Vorschreiten begriffen. Denn die vergeistigende Fackel beleuchtete hier nur die schönen Obertheile, und vehüllte die Restaurationsgräuel der treppenformigen Draperie und der abgefleischten untern Gliedmasen." Böttiger, Dresdner Antikengalerie, 2.

${ }^{9}$ On this phenomenon, cf.: J.J. L. Whiteley, "Light and Shade in French Neo-Classicism," The Burlington Magazine 117, no. 4 (1975): 768-773; Oskar Bätschmann, Ausstellungskünstler. Kult und Karriere im modernen Kunstsystem (Köln: Dumont, 1997), 21 et seq.; Michael Diers, "Nach-Lebende Bilder. Praxisformen klassizistischer Kunsttheorie," in Die schöne Verwirrung der Phantasie. Antike Mythologie in Literatur und Kunst um 1800, ed. Dieter Burdorf and Wolfgang Schweickhard (Basel: Francke, 1996), 175-205; Claudia Mattos, "The Torchlight Visit: Guiding the Eye through Late Eighteenth- and Early Nineteenth-Century Antique Sculpture Galleries," in Critical exchange: Art Criticism of the Eighteenth and Nineteenth Centuries in Russia and Western Europe, ed. Carol Adlam and Juliet Simpson (Bern: Peter Lang, 2009), 129-151. The only exception, taking also into account critical perspectives on this phenomenon, is the essay by Dominik Müller, "Statuenbelebung - realistisch. In Wilhelm Raabes 'Frau Salome' sowie Gottfried Kellers 'Regine' und 'Herr Jacques,'" Jahrbuch Raabe Gesellschaft (2004): 16-32, focusing, however, on a very different subject, namely literature of $19^{\text {th }}$ century German Realism.

10 "Place the light on the ground so as to throw the shadows upwards, and the best piece of antique sculpture will become absolutely ludicrous; introduce it either from one side or the other horizontally, and the figure becomes lopsided and disproportioned." Pamphlets on English public works and engineering (s.l., 1800), 23.

11. For the case of Cellini, cf. Horst Bredekamp, The Lure of Antiquity and the Cult of the Machine (Princeton, NJ: Markus Wiener, 1995), 1.
} 


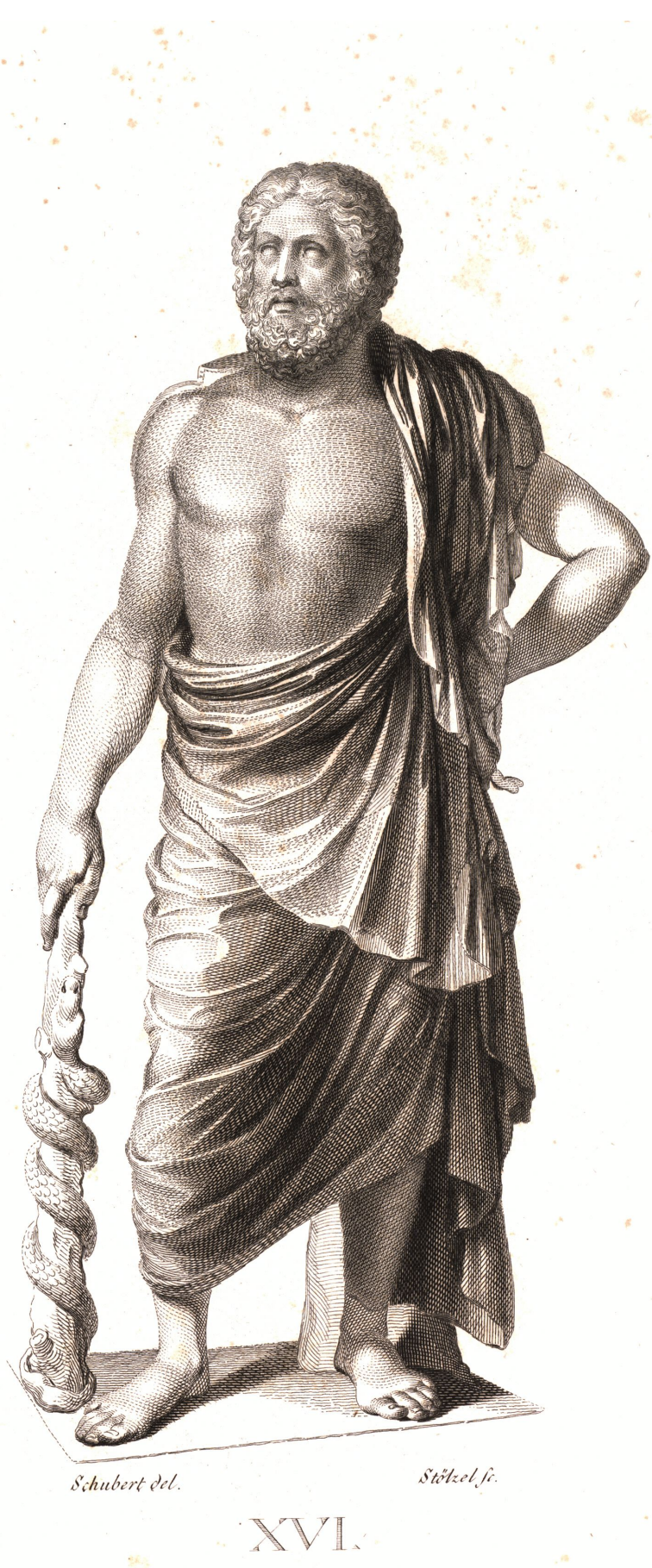

Figure 2

Aesculap, from Wilhelm Gottlieb Becker, Augusteum ou Description des Monuments Antiques que se trouvent a Dresde, Tome I (Leipzig: Hempel, 1804), plate XVI (photo: author). 
The most famous description of a visitation of this type and its desired effects is, of course, found in Goethe's "Italian Journey." The apparition of the statues in the light appeared to Goethe as a "dream floating along my soul."12 Other German travellers reported similar experiences. ${ }^{13}$ Karl Julius Weber praised the "ghostly lustre" of the illuminated marble, and he emphasized the "ceremonial grandeur and ease" evoked by this spectacle. ${ }^{14}$ Or, as Siebenkees wrote: "the stony image disappears, and you believe to see the goddess herself." ${ }^{15}$ This effect of the illusion of a living presence was visually documented most famously by Joseph Wright of Derby (Fig. 3), where young men touch and interact with a statue which seems to have become a living contemporary. In that case, illumination served as a kind of time machine, whereby the beholder was transported to the glorious days when the antique art was still gleaming and new.

Another reason for the popularity of this practice may have consisted in the growing conviction that the Ancients themselves regularly beheld their sculptures with artificial illumination. This practice thus enjoyed a certain aura of authenticity. Henry Matthews, for example, claimed that in antiquity, statues were mostly exhibited in windowless rooms; this thesis was notably picked up by Madame de Staël in Corinne ou I'Italie. ${ }^{16}$ Böttiger, on the contrary, was quite sceptical about the ancient nightlife. He claimed, for instance, that the Ancients regularly went to bed at dusk, for the sake of their waking power. ${ }^{17}$

Of course, the aim of art lovers such as Goethe and Weber was not to travel back in time or invoke a true historical transformation. Rather, they sought to experience a kind of ideal timelessness. As Siebenkees stated, to behold a statue in this way is to see the presence of a goddess: He felt transported to a mythical Greece, not subordinated to the flow of time. Consequently, he himself became (ideally, at least) an ancient Greek, worshipping the same idols they once venerated. Nevertheless, this supposed "historicist"

12 "[...] ein solcher genußreicher Umgang durch die herrlichsten Reste der Kunst, welcher meistenteils wie ein entzückender, nach und nach verlöschender Traum vor der Seele schwebt." Johann Wolfgang von Goethe, Italienische Reise, ed. Andreas Beyer and Norbert Miller (München/Wien: Hanser, 1992), 524.

13 English cases were also common, but it is striking that the phenomenon is more or less restricted to these two nationalities; in France, this mode of presentation became popular only after 1803. Cf. Marjorie B. Cohn and Susan L. Siegfried, Works by J. A. D. Ingres in the Collection of the Fogg Art Museum (Cambridge, Mass.: Fogg Art Museum, 1980), 44.

14 "Die Nacht und der Fackelschein wirft Geisterglanz über diese Versammlung der Götter und Heroen, die Phantasie erwärmt sich, und ergriffen von der Nähe des griechischen Genius wandelt man bebend durch die hochgewölbten Hallen, in jener feierlichen Würde und Ruhe, die Winkelmann als Charakter classischer Kunst bezeichnete." Karl Julius Weber, Deutschland; oder, Briefe eines in Deutschland reisenden Deutschen, vol. 3 (Stuttgart: Franckh, 1828), 178.

15 "Bey Nacht, beym Fackellicht, thut sie erstaunliche Wirkung; das steinerne Bild verschwindet, man glaubt die Gottheit selbst zu sehen." Johann Philipp Siebenkees, Handbuch der Archäologie oder Anleitung zur Kenntniß der Kunstwerke des Alterthums und zur Geschichte der Kunst der alten Völker, vol. 1 (Nürnberg: Stein, 1799), 279.

16 "Many of them [the statues] were found in baths, where light was not admitted. They were created therefore for torchlight as their proper element." Henry Matthews, The Diary of an Invalid, $2^{\text {nd }}$ ed. (London: Murray, 1822), 132; "Les anciens [...] les [the statues] placoient souvent dans leurs Thermes où le jour ne pouvoit pas pénétrer. A la lueur des flambeaux, I'ombre plus prononcée amortit la brillante uniformité du marbre." Anne Louise Germaine de Staël, Corinne, ou I'Italie (1807; nouvelle ed., New York: Leavitt \& Allen, 1857), 149.

17 "Nachtfeste und Spiele bei nächtlicher Beleuchung waren der Lebensart der Griechen und Römer ganz fremd." Böttiger, Ideen zur Kunst-Mythologie, 153. 
experience of the ancient statues, this time-travel to the revered past, is in fact fundamentally ahistorical. This point was made most explicit by Karl Philipp Moritz, who wrote that, in illuminating a sculpture, "all of a sudden our perception of time fades, and everything is condensed in one single moment, which seems to last forever." ${ }^{18}$ He was aiming at a mystical effect like the one shown in the frontispiece (Fig. 4) of the short-lived German journal Der Torso, where a "genius of art" (not an ordinary beholder) lights, and thereby animates, the eponymous statue. ${ }^{19}$

Because period descriptions of viewing antique sculpture by torchlight anticipated that the beholder will experience a certain extemporality, one might not be surprised that the practice of illuminating statues in this way was clearly less valued in the case of contemporary art, even though the practice seems to originate in drawing classes, viz., contemporary art practice (Fig. 5). When Corinne in Mme de Staël's famous novel visits the atelier of Canova by night, she remarks, after initially praising the effect that the statues seen in candlelight "appear as pale figures." ${ }^{20}$ This observation is stated even more explicitly by an anonymous German author, who wrote that, in the case of Thorvaldson, artificial illumination was aesthetically very counterproductive, because his sculptures then appear to be "only dull copies" (nur matte Copien) compared to the splendour of the Ancients. ${ }^{21}$ The reason for these ambiguous judgements may have been that there was no necessity for animating the already contemporary present.

Moritz was not the only author to emphasize the immersive effects torchlight had on the beholder. Heinrich Meyer, for example, claimed that, when illuminated by a torch, each and every statue is viewed as entirely isolated and independent. Thus, the artworks are no longer seen in a historical sequence, or in relation to other works in history, but as individual, timeless epiphanies. ${ }^{22}$ Shrouded in the cone of light, beholder and artwork may communicate eye to eye, and as equals. Karl Julius Weber described this immersive effect thusly: "under torchlight, you wander through the antiques to Mount Olympos, as the Greek once did." 23 An even more intense encounter was documented by an English traveller, who wrote that the Hercules Farnese "seemed to advance, half alive, from amid the darkness, and the flames appeared to tinge him with the warm colouring of an animated gigantic body." 24

\footnotetext{
18 "[...] so sieht man hier alles Schöne, was man sehen kann, auf einmal, der Begriff von Zeit verschwindet, und alles drängt sich in einem Moment zusammen, der immer dauern könnte." Karl Philipp Moritz, Reisen eines Deutschen in Italien in den Jahren 1786 bis 1788: In Briefen. Dritter Theil (Berlin: Maurer, 1793), 155 et seq. Here, he is describing the effect of a "paradoxen Zugleich einer bewegten Unbewegtheit," destined "die Veränglichkeit des Lebens imaginativ aufzuheben, indem die Dauer der Kunst für sie einzutreten bestimmt ist," as Harald Tausch analysed. See Harald Tausch, Entfernung der Antike (Tübingen: Niemeyer, 2000), 112.

${ }^{19}$ Cf. Ekkehard Mai and Kurt Wettengl, ed., Wettstreit der Künste (Wolfratshausen: Edition Minerva, 2002), Cat. Nr. 193.

${ }^{20}$ Staël, Corinne, 149.

21 "Thorwaldsens Werkstätte zu Rom," Iris: Unterhaltungsblatt für Freunde des Schönen und Nützlichen 1 (1827): 494-495.

22 "Vorteile der Fackelbeleuchtung: Jedes Stück wird nur einzeln abgeschlossen von allen übrigen betrachtet, und die Aufmerksamkeit des Beschauers bleibt lediglich auf dasselbe gerichtet." Goethe, Italienische Reise, 524.

23 "[...] unter den Antiken wandelt man im Fackelschein in den Olympos, wie die Griechen, wenn sie Phidias Jupiter zu sehen nach Olymp reisten." Weber, Deutschland, 53.

${ }^{24}$ Friedrich Carl Ludwig Sickler, "Account of the Regj Studj, or Royal Museum of Antiquities at Naples," The New Monthly Magazine VI (1816): 131.
} 


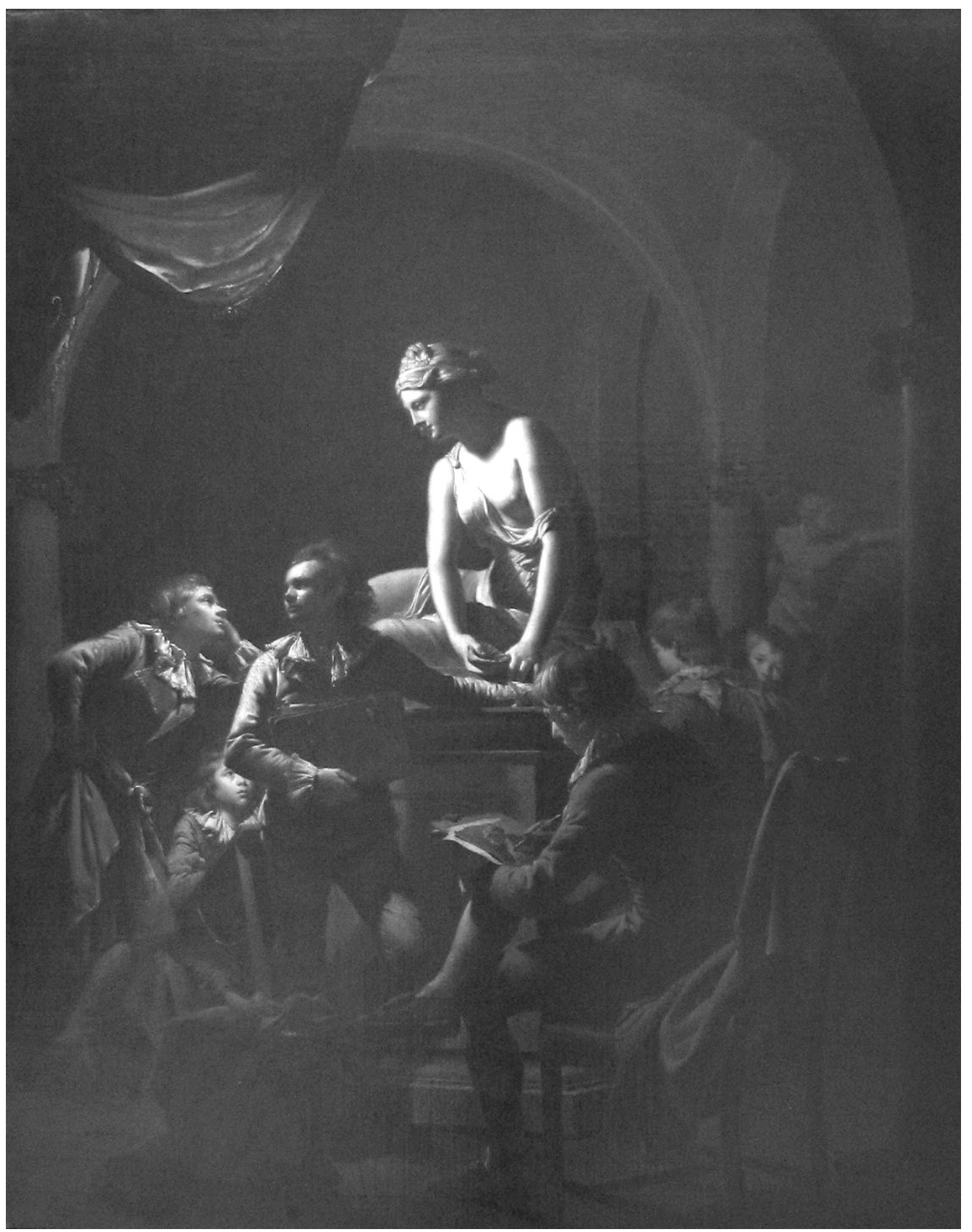

Figure 3

Joseph Wright of Derby, An Academy, 1769. Oil on Canvas, $127 \times 101.2 \mathrm{~cm}$. Yale Centre for British Art (photo: Wikimedia Commons). 


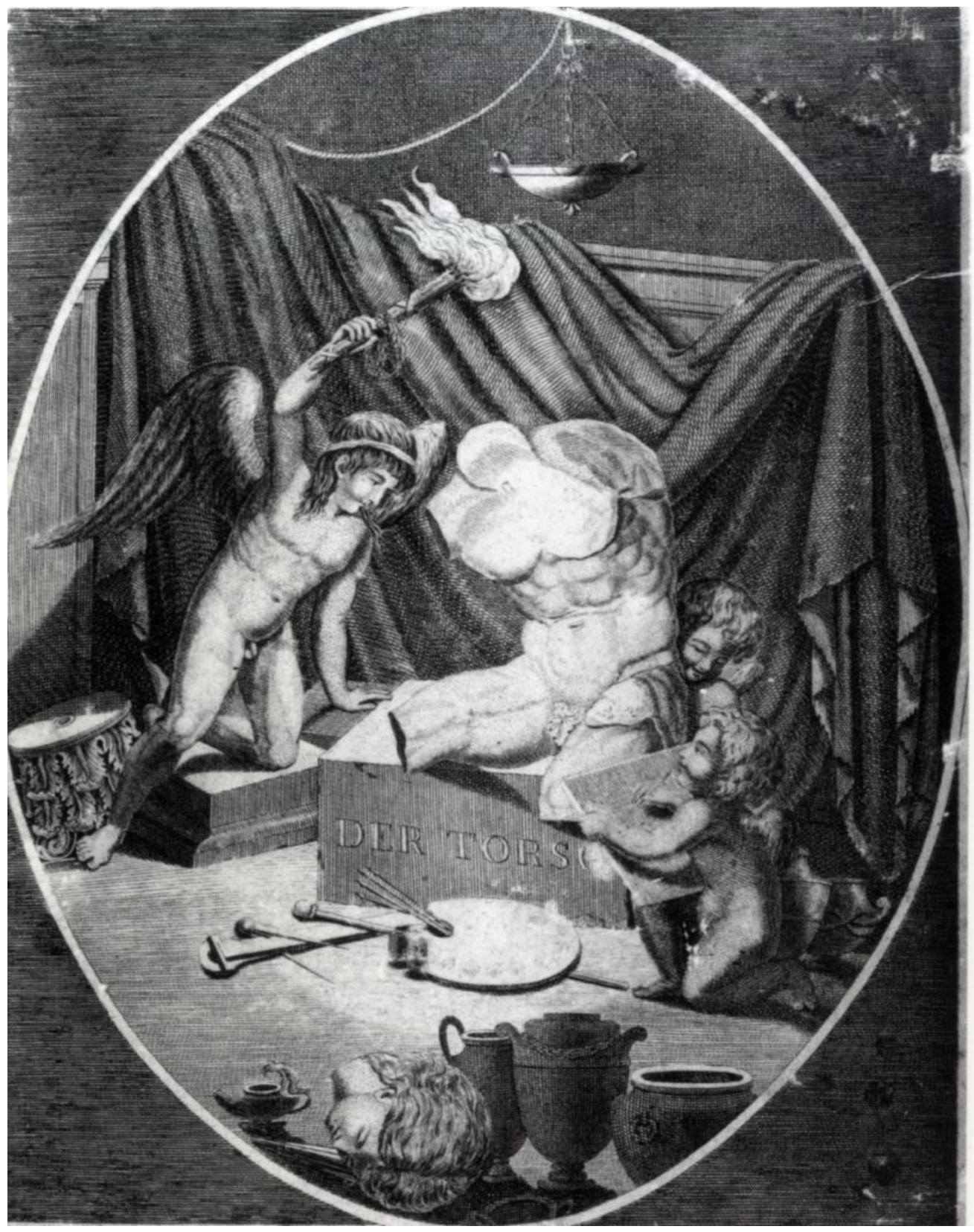

Figure 4

Frontispiece from Der Torso: Eine Zeitschrift der alten und neuen Kunst gewidmet, 1796. From Ekkehard Mai and Kurt Wettengl, ed., Wettstreit der Künste (Wolfratshausen: Edition Minerva, 2002), 415 (photo: author). 
Here, torchlight's enlivening effects actually appear to animate the statues. In fact, the late eighteenth century developed an array of possibilities for "animating" the antique. The presentation of sculptures on movable pedestals and, of course, the theatrical re-enactment of antique imagery, as practiced most famously by Emma Hamilton in her "'attitudes," are only two examples (Fig. 6). ${ }^{25}$ In both cases, the beholder remained more or less passive. By enlivening statues with torch in hand, he became something of an artist himself, some kind of new Pygmalion. For Böttiger, too, the idea of physical contact, or what Victor Stoichita called the "Pygmalion-Effect" (viz., the coalescence of the bodies), seemed to be the ideal. He wished "to touch the flesh, to see whether it gives way to the pressure of my fingers." 26

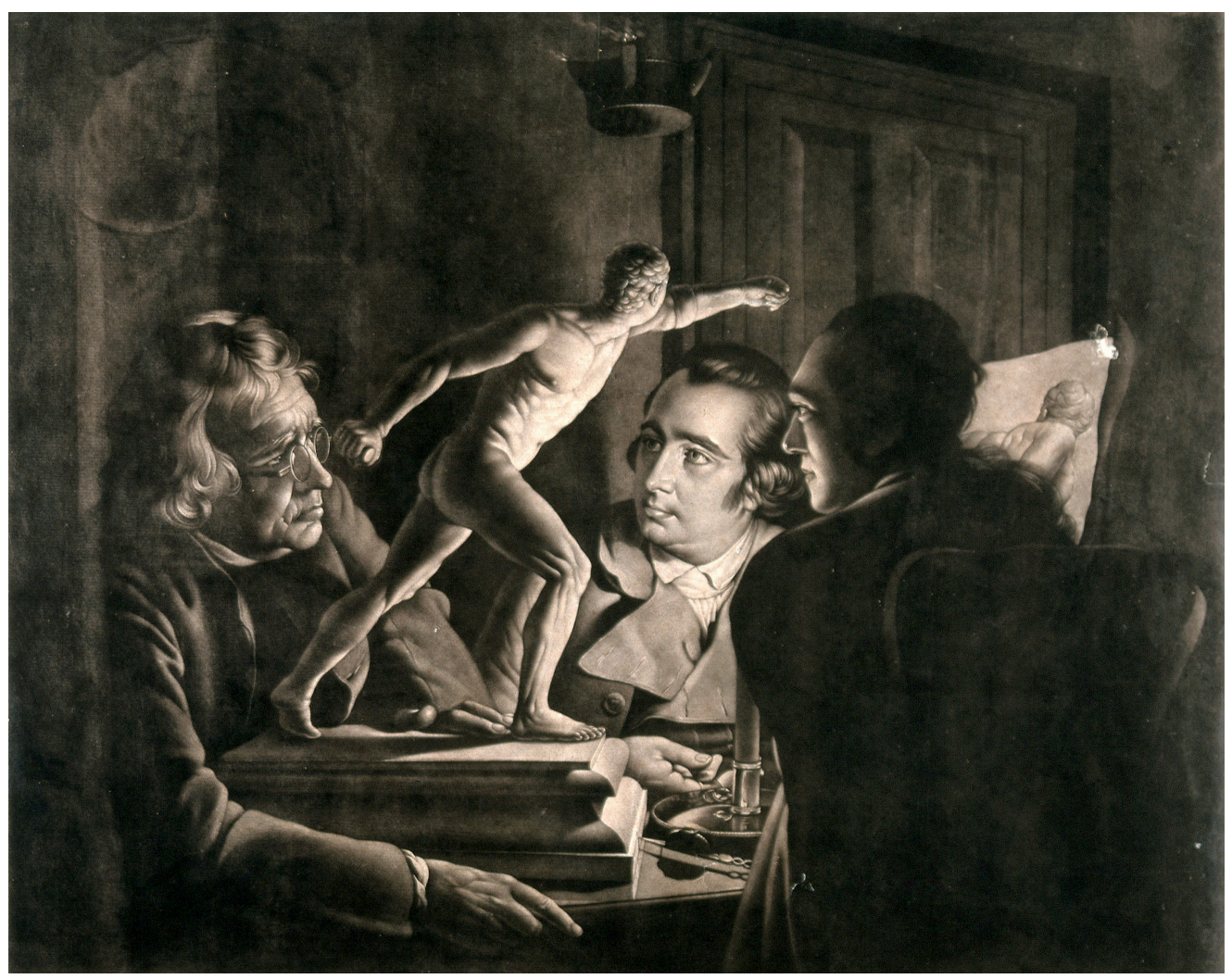

\section{Figure 5}

5 William Pether after Joseph Wright of Derby, Three men at a table, studying the figure of the 'Gladiator,' 1769. Mezzotint, 471x554mm (photo: Wikimedia Commons).

\footnotetext{
${ }^{25}$ Christian M. Geyer, "Bewegliche Sockel für antike Statuen und deren Abgüse," in Gipsabgüsse und antike Skulpturen, ed. Charlotte Schreiter (Berlin: Reimer, 2012), 95-114. Alicia Craig Faxon, "Preserving the Classical Past: Sir William and Lady Emma Hamilton," Visual Resources 20 (2004): 259-273.

${ }^{26} \mathrm{He}$ "wünscht das Fleisch zu betasten, ob es dem Fingerdruck weiche." Böttiger, Dresdner Antikengalerie, 7 et seq. For an analysis of the "pygmalion effect," see Victor I. Stoichita, L'effet Pygmalion: Pour une anthropologie historique des simulacres (Genève: Droz, 2008).
} 
The main critique against the practice of "enlivening" statues by torchlight was that the sculptures seemed to become a bit too alive. A telling statement to this effect was made by Bonaventura in his "Nachtwachen." Here, the author describes how a group of young men approach a statue of Venus in torchlight and, subsequently kiss and caress the marble (a scene, again, resembling the paintings of Wright of Derby). Bonaventura's description of this event does not evoke a marvellous unification with the past but rather an uncanny conjuration of their ghosts. ${ }^{27}$ In fact, the idea of enlivening images with artificial light seems to be closely related with much-criticized illusionistic practices such as the laterna magica and similar optical spectacles, often understood as devices of deceiving, especially indicted by Protestant authors claiming these practises were part of a corrupting Catholic seduction. ${ }^{28}$ It is all the more interesting that the protagonists quoted here are nearly all Protestants, a group seemingly more prone to the epiphanies offered by the idols of art venerated in a quasi-religious manner.

The case of Böttiger, who discovered through the illumination only detested restorations, runs contrary to this model. Finding the images "abused," as he wrote, his torch resembled less the chisel of Pygmalion, and even less the torch of Prometheus, than the light of an excavator that illuminates the sediments of modern stone which are burying the true antique. Here, he acts like travellers such as Charles Dupaty, lighting rough terrain: "To see the theatre of Herculaneum, you must descend under a damp vault, by torch light, and wander, a long time." Described here is a scientific view, as practised by an author in the Journal of Natural Philosophy, Chemistry, and the Arts, who was trying to identify a forged antique gem, "examining it by torchlight, and at some distance." 29

For Böttiger, antiquity was not directly accessible by imagination, as it was for Moritz, who was able to get there "all of a sudden." His antiquity was located in what may be called a "vertical history," more complex and multi-layered than the clear dichotomy of "ancient" and "modern" many of his contemporaries drew. Böttiger approached the artwork only from the outside, unable to penetrate its potentially living core - a strategy which only disappointed him. The impression he received in front of a candelabrum was typical for him (Fig. 7; see also Fig. 1). Enthusiastically, he described "how sharp the contour of this unique three-cornered base of a candelabrum is protruding in the light of the torch." But the light in his hand stayed in front of the candleholder; Böttiger may illuminate it, but he could not reinstall the light on the candelabra where it originally belonged. He capitulated with a sigh of sorrow: "O, would only this holy flame blaze above it." ${ }^{30}$ The light helped to examine the object, but he remained unable to bring it back to life and to reinstate it to its original function.

\footnotetext{
${ }^{27}$ Cf. Müller, "Statuenbelebung," 18.

${ }^{28}$ Cf., among many others, Barbara Maria Stafford, Artful Science: Enlightenment and Entertainment and the Eclipse of Visual Education (Cambridge, Mass: MIT Press, 1994); Gerard Vaughan, "'A Kind of Magick:' Art, Deception and Illusion in Later Georgian England," in Geschichte und Ästhetik, ed. Margit Kern, Thomas Kirchner and Hubertus Kohle (München/Berlin: Deutscher Kunstverlag, 2004), 209-218.

${ }^{29}$ Charles Dupaty, Travels through Italy (London: G.J. And J. Robinson, 1788), 327. Guyton, "Account of the Antique Vessel that was preserved at Genoa," A Journal of Natural Philosophy, Chemistry and the Arts 18 (1807): 97.

30 "Wie scharf zeichnen sich die Umrisse der unvergleichlichen dreieckigen Candelaber-basis mit dem Dreifuss-raub hier gegen den Fackel-schimmer! O loderte die heilige Flamme noch über ihm!" Böttiger, Dresdner Antikengalerie, 1.
} 


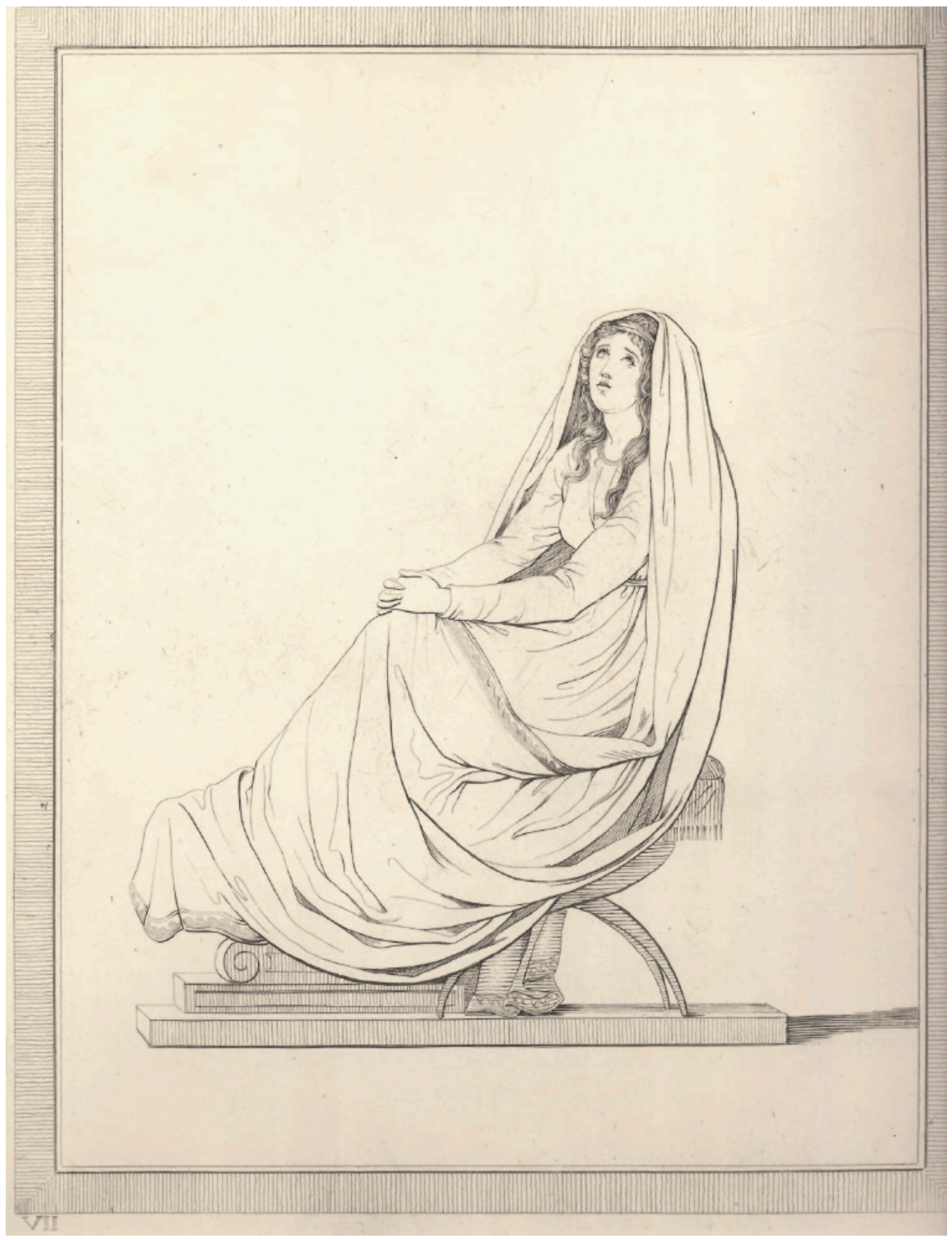

Figure 6

Lady Hamilton's "attitudes," from Friedrich Rehberg, Drawings Faithfully copied from Nature at Naples (London: S.W. Fores, 1797), unpag. (photo: author). 


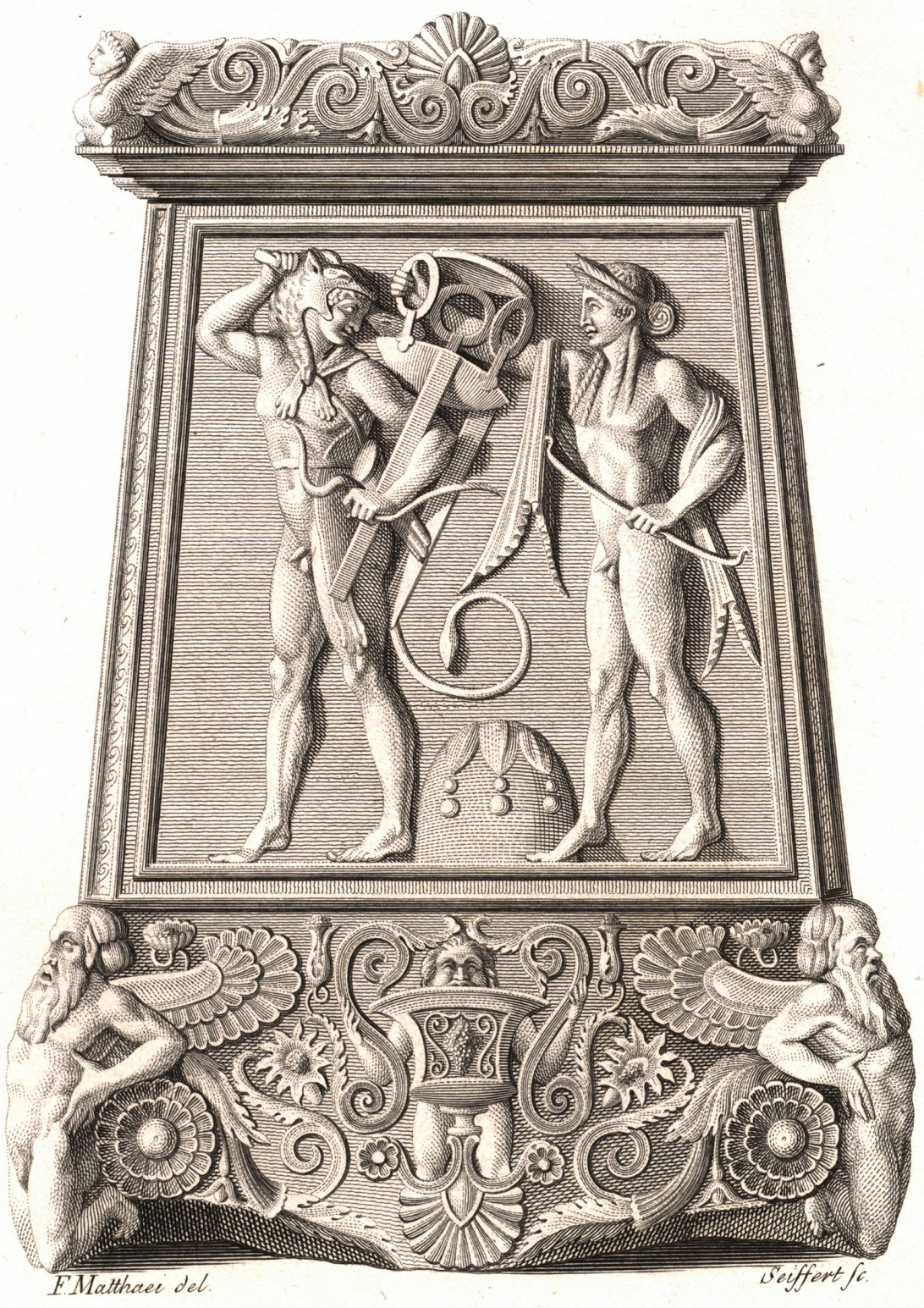

Figure 7

Candelabrum, in: Becker, Augusteum, plate V (photo: author). 
The torchlight acted as a sober and more scientific form of illumination. Such a rational approach, represented for example in Benjamin Zix's drawing of Napoleon visiting the Louvre, ${ }^{31}$ was definitely not what the majority of the lovers of antiquity were interested in (the Englishman quoted above, pleading for top-lit galleries, was a notable exception). Only later in the $19^{\text {th }}$ century did illuminating art galleries all-over by a roof light become ubiquitous. ${ }^{32}$ Participants in a tour like Böttiger's were not interested in historical or scientific ballast, rationalizing their emphatic experience of the artworks. His lectures perhaps offered a too realistic, too worldly outlook on the ancient societies. It is thus not surprising to hear that there were multiple reports of visitors who participated in Böttiger's tours leaving unconvinced by his academic approach of pointing out restorations. Caspar David Friedrich and Ludwig Tieck, for example, both complained that Böttiger failed to communicate the deeper artistic values of the objects. Tieck wrote that he "described mainly superficial and negligible aspects, but didn't penetrate the deeper artistic meaning of the artworks." ${ }^{33}$ They, too, were missing the enlivening Promethean touch Böttiger himself had not found.

For Böttiger, the statues' real presence inhibited a perception of their "ideal presence," as Lord Kames would have called it. But for this ideal presence it was a prerequisite to have an imaginative free space. Only then would the beholder be able to fall in the "waking dream," a "kind of reverie" that Kames defined as the characteristics of an "ideal presence." ${ }^{34}$ Winckelmann was able to enjoy antique art in just this way, paradoxically because it was damaged and long-time past. ${ }^{35}$ His most emphatic descriptions were dedicated to statues that were conserved only in fragments, as, most famously, in the case of the Torso Belvedere - one of the rare antiques that had never undergone restoration and was always preserved as a fragment. The non-finito of the statue is the pre-condition of the imaginative expansion Winckelmann so masterly evoked. The best visual adoption of this thought may be seen again in the already-mentioned frontispiece of the German journal Der Torso. Only in view of the blank spaces could the beholder's eyes get a starting point for his purely imaginary reconstruction. Again, with this creative re-imagination of the animating work of the artist, the beholder became a true Pygmalion himself.

But not only did the fragmentary state of preservation open the way for antiquarian imagination; it also guaranteed that the beholder could hold a piece of "pure" antiquity before his eyes. And it was exactly this of which Böttiger was unsure. Even filtering out the true, unrestored core of a sculpture (a discrimination in certain cases already visualized in

\footnotetext{
${ }^{31}$ On this drawing, see Whiteley, "Light and Shade," and Europa 1789: Aufklärung, Verklärung, Verfall, ed. Werner Hofmann (Köln: Dumont, 1989), cat. nr. 482.

32 On the history of roof-lit galleries: Ruth Guilding, "Robert Adam and Charles Townley. The development of the top-lit sculpture gallery," Apollo 143 (1996): 27-32.

33 "Bei wiederholten Gelegenheiten bin ich Zeuge davon gewesen, dass er alsdann mit einem Schwall von gelehrten Redensarten vieles Aeußerliches und Nebensächliche beschrieb und der tiefsinnig künstlerischen Bedeutung des betreffenden Kunstwerkes kaum eine Andeutung widmete." Hermann von Friesen, Ludwig Tieck. Erinnerungen eines alten Freundes aus den Jahren 1825-1842, vol. 1 (Wien: Braumüller, 1871), 64. And Friedrich wrote: "Hier führte der allwissende Böttiger bei Fackellicht zu den Antiken und hielt seine modischen Vorlesungen, die man schwer verstand." Caspar David Friedrich, Bekenntnisse, ed. Kurt Karl Eberlein (Leipzig: Klinkhardt \& Biermann, 1924), 7.

${ }^{34}$ Henry Home Kames, Elements of Criticism, vol. 1 (London: Bell and Creech, 1788), 90 et seq. Cf. Eric Rothstein, "'Ideal Presence' and the 'Non Finito' in Eighteenth-Century Aesthetics," Eighteenth Century Studies 9 (1976): $307-332$.

${ }^{35}$ For this figure of thought, see: Peter Geimer, Die Vergangenheit der Kunst: Strategien der Nachträglichkeit im 18 Jahrhundert (Weimar: VDG, 2002).
} 
the illustrations of the catalogues of the Dresden gallery (Fig. 8), even before the restorations were finally removed) did not prove successful. ${ }^{36}$ In more than one case, Böttiger had to admit that the first restorations were most probably already made in antiquity. The monolithic view of "the" antique as an extemporal asylum of a pure and perfectly well-ordered world collapsed with this insight. The antique already produced temporally multi-layered objects, and their histories reached out to the present.

Böttiger thus lacked the experience of historical distance to the antique that his contemporaries both felt and bridged by various devices of imagination. Paradoxically, he failed at perceiving the godly presence of the antique, because he realized that the sculptures were more contemporary then he wanted them to be. In admitting that some restorations were already made in antiquity, Böttiger had to realize that the Ancients were in no way better than the moderns; their behaviour may have been, in fact, quite similar to what Böttiger witnessed in his own, debased present. Antiquity thus lost its character as a utopian past but rather appears very modern, in some respects. The "object biographies" of the antique statues present themselves as a series of restorations, going on uninterruptedly from the time of their making through the present.

Nevertheless, this shape of time does not seem to be the same as a concept of "survival" that might be associated with authors such as Richard Payne Knight or Karl Philipp Moritz. ${ }^{37}$ According to the latter, in mythology (and mythological artworks), there is a "secret trace leading back to the oldest, long lost history" to be found. ${ }^{38}$ The history of art, therefore, is to be understood as an uninterrupted thread leading back to the origins of art. Moritz's "traces" were quite literally illustrated by a mode of depiction that is conceivably different to the three-dimensional plastic forms Böttiger encountered. His Götterlehre was illustrated by outline engravings (Fig. 9) - a popular style that corresponds neatly with the idea of a "trace," a surviving remnant of the former abundance of classical beauty. ${ }^{39}$ Even Winckelmann had a vision of such a relationship with the antique when, in the famous final scene of his Geschichte der Kunst des Altertums, he stylized himself as a (female) lover, standing on the shore, and "follows with tearful eyes her departing sweetheart, with no hope of seeing him again, and believes she can glimpse even in the distant sail the image of her

\footnotetext{
${ }^{36}$ The restorations were finally taken off only around 1900 by Georg Treu, cf. Kordelia Knoll, "Zur Entstehung der Dresdner Antikensammlung," in Von der Schönheit weißen Marmors, ed. Thomas Weiss (Mainz: Zabern, 1999), 64, and Kordelia Knoll, "Ein wirkliches Rettungswerk. Zur sog. Entrestaurierung der Dresdner Antiken," in "Wiedererstandene Antike": Ergänzungen antiker Kunstwerke seit der Renaissance (München: Biering \& Brinkmann, 2003), 223-227.

${ }^{37}$ For Böttiger's interest in Knight's writings, see: Karl August Böttiger, "Ueber Richard Payne Knight," Amalthea 3 (1825): 408-418. On Knight's theory of 'survivals', see Whitney Davis, Queer Beauty (New York: Columbia Univ. Press, 2010), chapter 2; Hans Christian Hönes, Kunst am Ursprung: Das Nachleben der Bilder und die Souveränität des Antiquars (Bielefeld: transcript, 2014), chapters 4 and 5.

38 Pictures are, for him, "eine geheime Spur zu der ältesten verlohren gegangenen Geschichte." Karl Philipp Moritz, Götterlehre oder mythologische Dichtungen der Alten (Berlin: Unger, 1791), 3. Cf. Michael Thimann, "Vergangene Wirklichkeit oder Sprache der Phantasie? Transformationen der Götterbilder bis um 1800: Montfaucon, Winckelmann, Moritz," in Götterbilder und Götzendiener in der Frühen Neuzeit, ed. Maria Effinger, Cornelia Logemann and Ulrich Pfisterer (Heidelberg: Winter, 2012), 23-35.

${ }^{39}$ Cf. Ulrike Münter, "Gebannter Bilderrausch. Bild und Text in Karl Philipp Moritz' Götterlehre," in Karl Philipp Moritz in Berlin 1789-1793, ed. Ute Tintemann and Christof Wingertszahn (Hannover: Wehrhahn, 2005), 39-56; Thimann, "Vergangene Wirklichkeit," 29.
} 
lover." ${ }^{40}$ This image of the lover, this silhouette in the sail, strongly resembles the shadow the legendary Dibutades circumscribed (Fig. 10) - again a linear "trace" leading back to the origins, the founding scene of art, and art history.

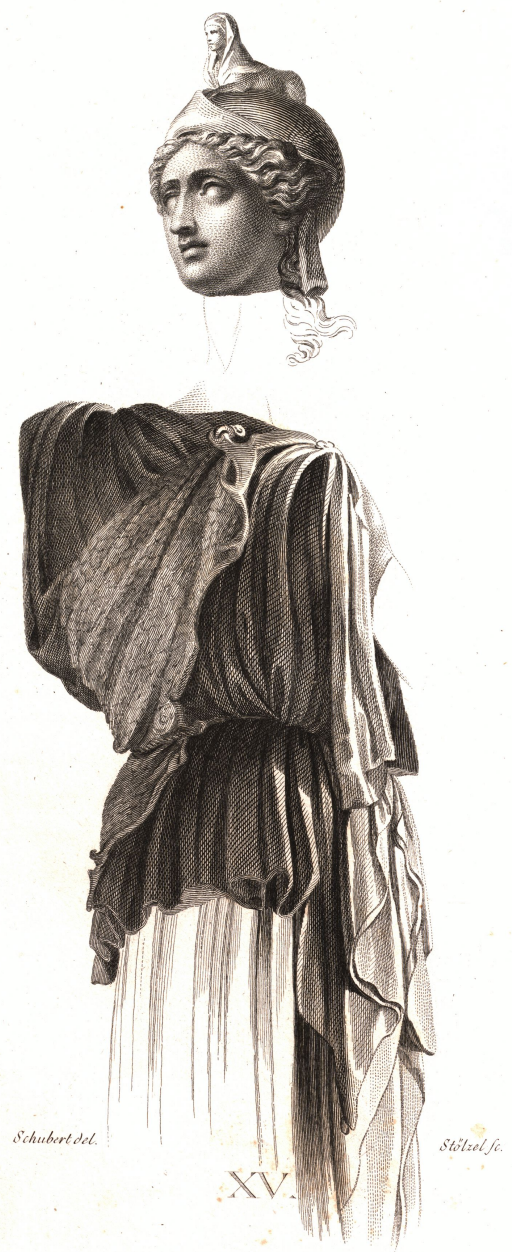

\section{Figure 8}

Restaurated statue, from: Becker, Augusteum, plate XV (photo: author).

40 Johann Joachim Winckelmann, History of the Art of Antiquity, trans. Harry Francis Mallgrave (Los Angeles: Getty Publications, 2006), 351. 


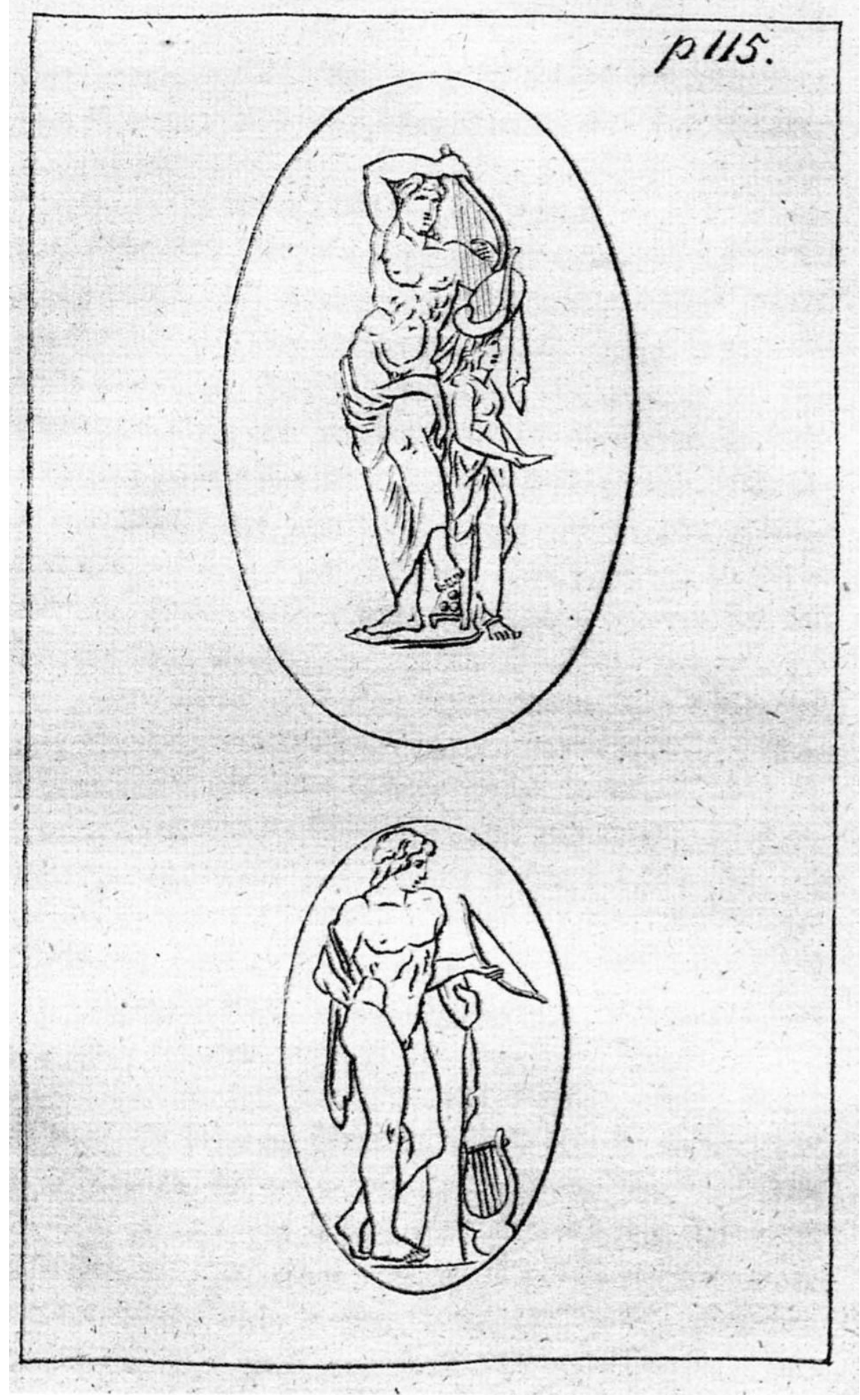

Figure 9

Jean Joseph Tassaert after Asmus Jakob Castens, Apollo, from Karl Philipp Moritz, Götterlehre (Berlin: Unger, 1791), 325 (photo: University Library Heidelberg). 


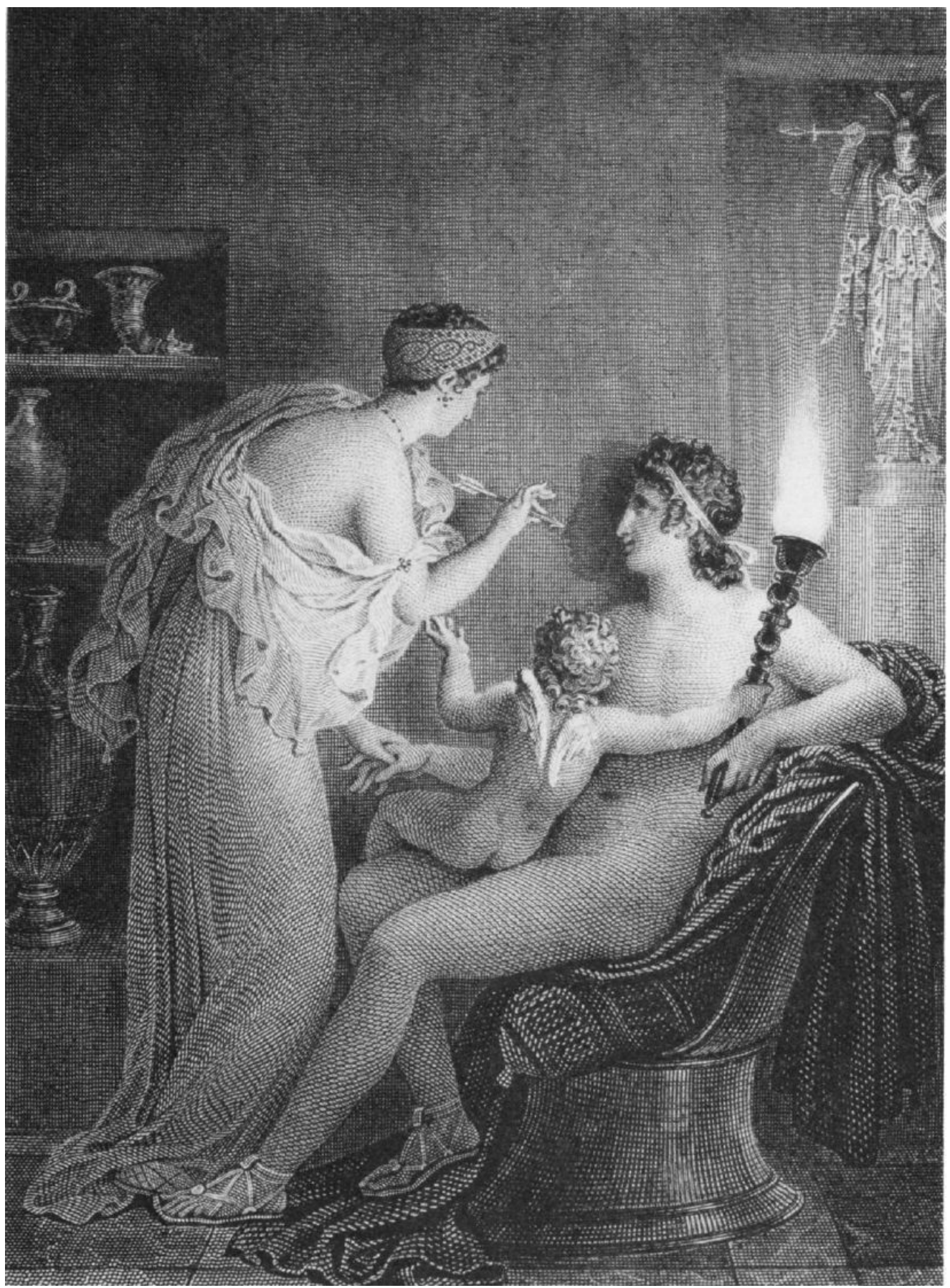

Figure 10

Louis-Pierre Henriquel-Dupont after Anne-Louis Girodet, The Origin of Painting, from Oeuvres Posthumes de Girodet-Trioson, Peintre d'Histoire, ed. P.A. Coupin (Paris: Jules Renouard, 1829), unpag. (photo: author). 
These ideas are profoundly grounded in the platonic assumption that the traces present in the visual manifestation of the artwork lead back to no "real things," but pure ideas. As Moritz wrote, the traces of the original myth "stand outside any context with the real things." But these "real things" were the ones with which Böttiger was confronted. Their material presence hindered him from seeing them as purely spiritual, purely antique, apparitions.

In fact, already naming the sculptures depended on their multi-layered history. The best example is the much-praised statue of the above-mentioned "Aesculap," today interpreted as a Zeus by Phidias (Fig. 11). His identifying (and name-giving) attribute, the snake-entwined staff, was a baroque addition. The torchlight revealed that the antiques, from the beginning, were palimpsests, a body of stone that had more than just one place in history (even in antique history). The statues appeared to be anachronistic in themselves; they had already experienced too much history to be viewed as purely spiritual anymore. When Winckelmann was weeping over the trace of his departed lover, he had only a memory image left, but this image was entirely his own - memories don't have to be shared. The restored statues Böttiger saw had, on the contrary, uncounted lovers. These innumerable Cavaceppis penetrated the statues' formerly pure marble with their dirty hands and left their marks. Böttiger, living in the poorest state of modern history, was put off by "modern botch, mated with antique artworks in an incomprehensible manner"; the "molested images" had lost their innocence." ${ }^{41}$

In the end, Böttiger had to capitulate to the aporia of his experience. He attempted to rescue his image of antiquity by returning to the grace of darkness: "Away with the torch, so the ugliness of the absurd restorations may not cause disgust." ${ }^{42}$

Böttiger tried to get rid of his unexpected and unwanted impressions and repress the fearful image of anachronistic sculptures. But this repression did not succeed; in fact, Böttiger participated - if only in imagination - in rewriting the palimpsest into even more complex and absurd figures. What happened here seems to share the characteristics of a psychological trauma, an enduring repeating of overwhelming events. In his sorrow of seeing two "molested" images standing side by side, Böttiger proposed to recombine the original antique substance of the much-praised upper parts of his beloved Aesculap with the antique parts of a Minerva (at least he thought this sculpture to represent one; Fig. 12). ${ }^{43}$ That is, he pleaded to create a monstrous recombination of the two sculptures - hermaphroditic and iconographically nonsensical. Böttiger's illumination ultimately did not lead back to an original perception of the antiques, which itself may have never had existed. Rather, it added to their history and carried their palimpsestic rewriting yet another step further.

41 In Dresden, he observed how "das Mittelmässigste mit dem Vortrefflichsten, modernes Machwerk mit antiker Kunstschöpfung auf die unbegreiflichste Weise [sich] zusammenpaarte." Karl August Böttiger, Kleine Schriften archäologischen und antiquarischen Inhalts, vol. 3 (Dresden/Leipzig: Arnold, 1838), 32.

42 "Doch weg mit der Fackel, dass uns die Hässlichkeit der sinnlosen Ergänzung nicht mit Widerwillen erfülle!" Böttiger, Dresdner Antikengalerie, 3. Nevertheless, Böttiger, didn't remove the restorations, even after he became supervisor of the Dresden collection. There may have been political reasons: Böttiger came into office during the very liberal Prussian-Russian government in Dresden, installed during the seven-year-war. After the restitution of the Saxonian Kingdom (1815), his ideas of antique art as a symbol of democratic freedom were no longer officially supported. Cf. Julia Schmidt-Funke, Karl August Böttiger (Heidelberg: Winter, 2006), 107; Boller, "Die Dresdner Antikensammlung," 138 et seq.

43 "O könnte aus den zwei hier vorhandenen, so gemishandelten Bildern ein alter Meister aus der Minervenstadt ein gutes erschaffen!" Böttiger, Dresdner Antikengalerie, 2. 


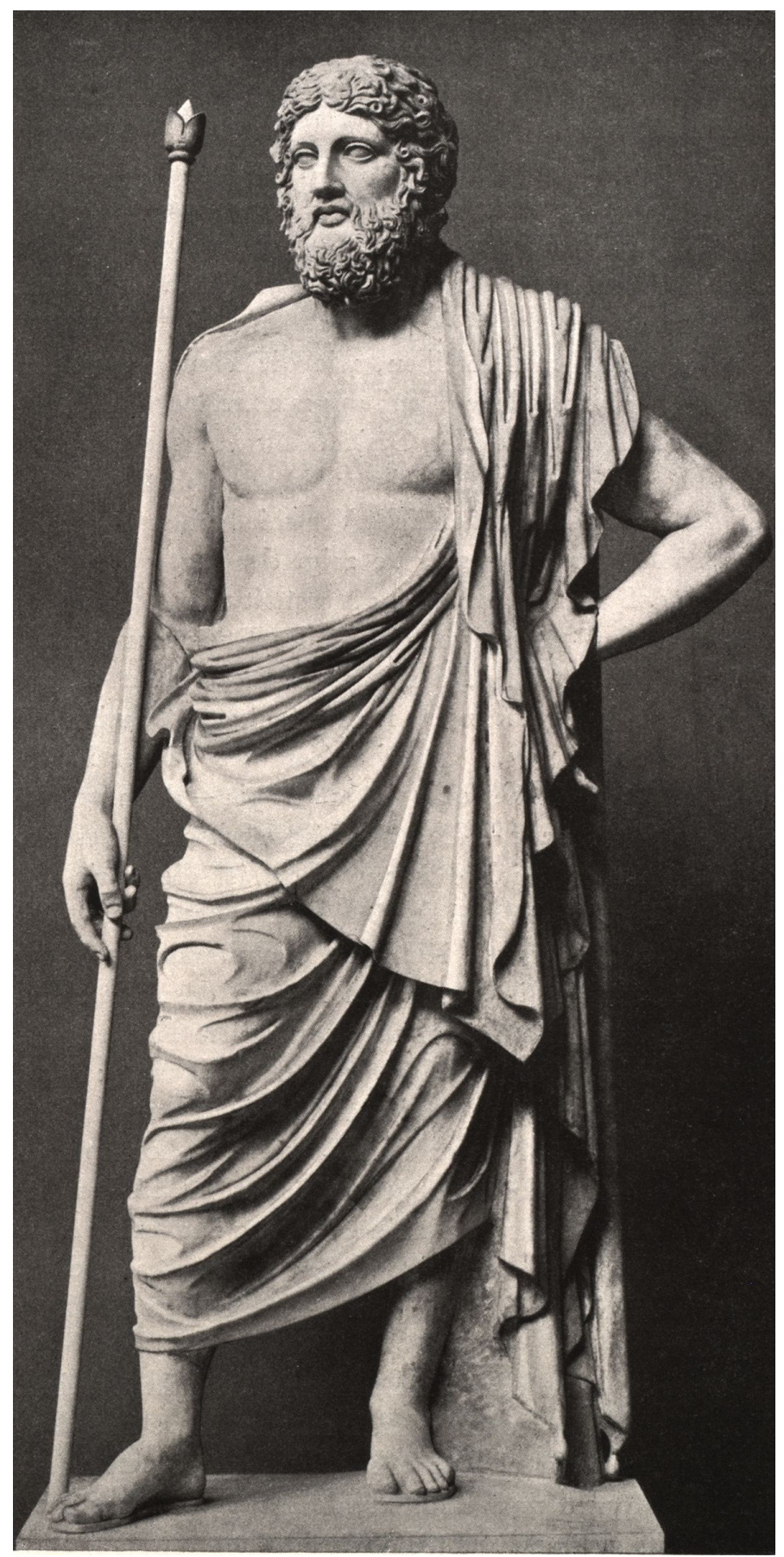

Figure 11

Dresden Zeus, from Hans Schrader, Phidias (Frankfurt a.M.: Frankfurter Verlags-Anstalt, 1924), 59 (photo: author). 


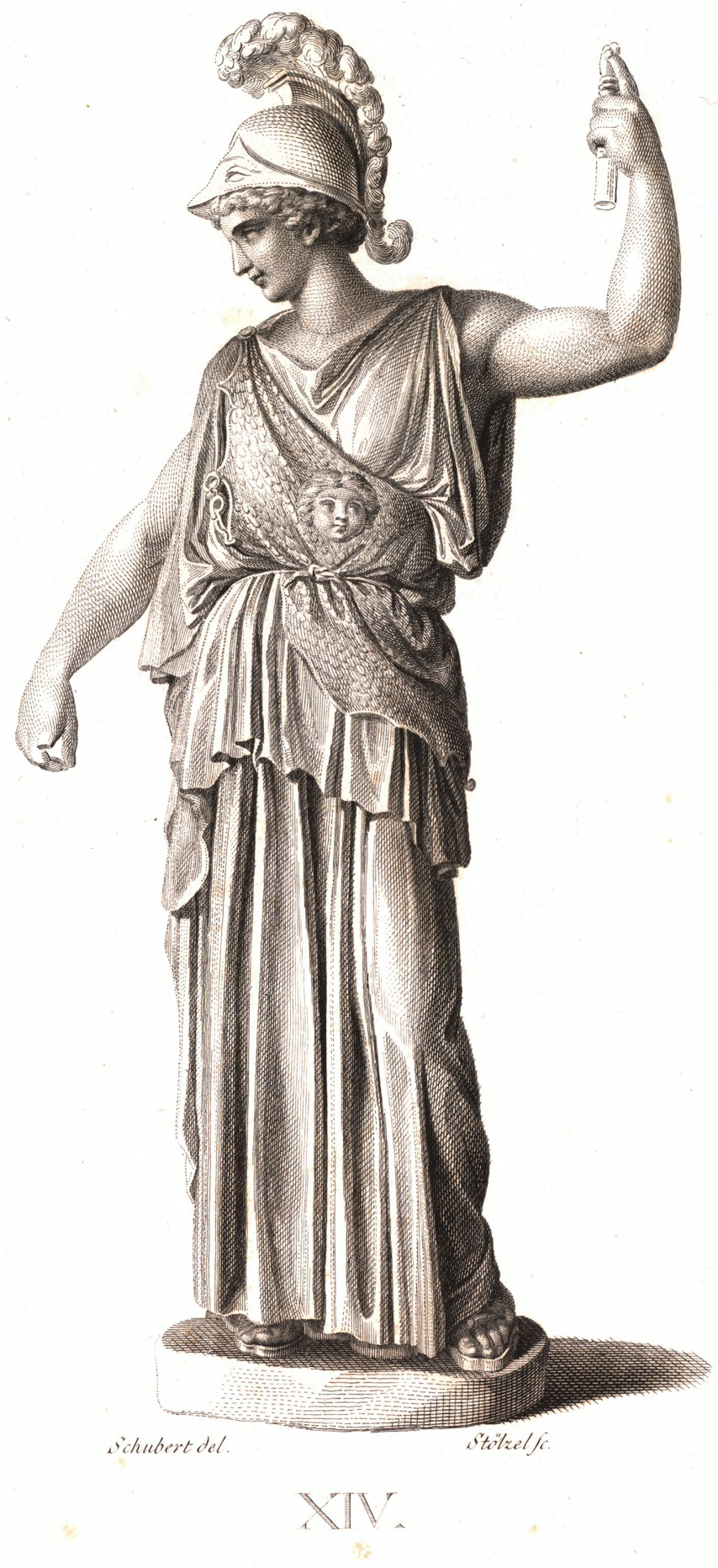

Figure 12

Minerva, in: Becker, Augusteum, Plate XIV (photo: author). 


\section{Acknowledgements:}

For valuable suggestions and comments on this paper, I'd like to thank Karen Appel, Eckart Marchand, and Elizabeth J. Petcu. A first version of this text was presented at the conference Moving in Three Dimensions: A Conference on Sculpture and Change, organized by Jim Harris at the Courtauld Institute of Art in London in May 2012. 
(cc) $\mathrm{EY}$

New articles in this journal are licensed under a Creative Commons Attribution 4.0 United States License.

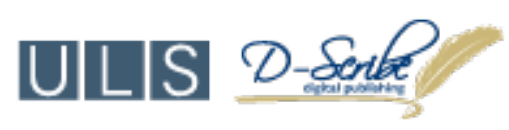

This journal is operated by the University Library System of the University of Pittsburgh as part of its D-Scribe Digital Publishing Program, and is co-sponsored by the University of Pittsburgh Press. 